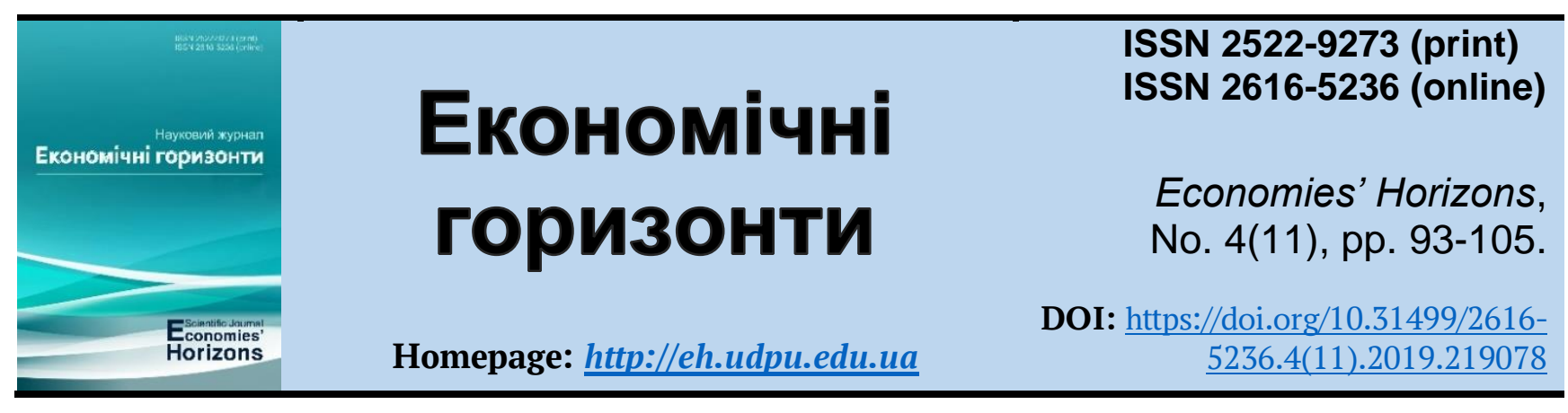

UDC 658.5:338.5

\title{
Elaboration of scientific and methodological approaches to providing eco- nomic security of an enterprise as a key component of its management
}

\author{
Volodymyr Ya. Nusinov ${ }^{1}$, Doc. Ec. Sc., Professor \\ Ievgeniia V. Mishchuk ${ }^{2}$, Cand. Ec. Sc., Associate Professor
}

Received: 2 November 2019

Accepted: 5 December 2019

Nusinov, V. Ya. and Mishchuk, le. V. (2019), "Elaboration of scientific and methodological approaches to providing economic security of an enterprise as a key component of its management", Economies' Horizons, no. 4(11), pp.93-105, doi: https://doi.org/10.31499/2616-5236.4(11).2019.219078

Abstract. The purpose of the research. The purpose of the article is to elaborate scientific and methodological approaches to providing economic security of an enterprise as a key component of its management. Methodology. The study applies general scientific theoretical methods - generalization, explanation, grouping - to analyzing economists' and practitioners' ideas about the object of the research and formulating conclusions of content analysis of primary sources, analysis and synthesis - to substantiating a new scientific approach to ensuring economic security of an enterprise. Results. Specific features of economic security of an enterprise as an object of management are taken into account as those revealing themselves in nonlinearity of links between its current level and the implemented set of managerial actions. To assess the results of ensuring economic security, its dynamic parameters have been substantiated including those of operational excellence as an internal prerequisite of its provision and market sustainability as an external form of manifesting internal systemic characteristics of a business. A methodological approach to assessing results of ensuring economic security of an enterprise is suggested on the basis on assessing the degree of correspondence of the above parameters (provision planes) to enterprises' internal standards, industry averages and the best current business practices. Implementation of the suggested methodological approach to assessing the results of ensuring economic security in retrospective enables empirical confirmation of the fact that internal operating prerequisites and market positions of mining and metallurgical enterprises are determined by used/unused opportunities of the business environment for a certain period of time. Styles of ensuring the economic security of the enterprises under study are identified. It is revealed that the regressive style, which manifests itself in overestimation of internal standards with a dangerous degree of compliance with the best business practices is prevailing. It has been substantiated that its use puts the economic security level in a critically dangerous dependency on the market situation and, taking into account current trends in the economic and political environment, makes it possible to predict a decline in the economic security level of the enterprises under study in the near future: the global economic decline, increased protectionism on the

\footnotetext{
${ }^{1}$ Kryvyi Rih National University; Professor at the Department of Accounting, Taxation, Public Management and Administration; ORCID ID: https://orcid.org/0000-0002-9293-2969; e-mail:vladimir.ya15@gmail.com

${ }^{2}$ Kryvyi Rih National University; Associate Professor at the Department of Accounting, Taxation, Public Management and Administration; ORCID ID: https://orcid.org/0000-0003-4145-3711; e-mail: tdutybz.077@gmail.com.
} 
markets, increased tax burden, increased environmental tax rates, etc. Practical importance. A scientific approach to ensuring economic security of an enterprise has been substantiated which integrates the strategic and operational levels of management and ensures minimization of the degree of inconsistency of the internal system characteristics of the business with stakeholders' e requirements and trends in the external environment based on the use of opportunities for increasing value added streams in the context of permanent dynamic changes in the functioning of the enterprise. Further research is devoted to development of methodological approaches to taking into account the third plane of ensuring economic security - "stakeholder satisfaction".

Keywords: economic security, provision planes, operating plane, assessment, market plane, management paradigm.

JEL Classification: C43, H56, J28.

Number of references: 11; number of tables: 3; number of figures: 1; number of formulas: $\mathbf{1}$.

\title{
Розвиток науково-методичних підходів до забезпечення економічної безпеки підприємства як ключового складника управління нею
}

\author{
Володимир Якович Нусінов ${ }^{1}$, д. е. н., професор \\ Євгенія Володимирівна Міщук ${ }^{2}$, к. е. н., доцент
}

Стаття надійшла: 02.11.2019

Стаття прийнята: 05.12.2019
Nusinov V. Ya., Mishchuk le. V. Elaboration of scientific and methodological approaches to providing economic security of an enterprise as a key component of its management. Економічні горизонти. 2019. № 4(11). С.93-105. DOI: 10.31499/2616-5236.4(11).2019.219078

Анотація. Мета дослідження. Метою статті є розвиток науково-методичних підходів до забезпечення економічної безпеки підприємства як ключового складника управління нею. Методологія. У дослідженні застосовуються загальнонаукові теоретичні методи: узагальнення, пояснення, групування - для аналізу поглядів економістів і практиків на об'єкт дослідження та формулювання висновків контент-аналізу первинних джерел, аналіз і синтез - для обгрунтування нового наукового підходу забезпечення економічної безпеки підприємства. Результати. Ураховано специфічні ознаки економічної безпеки підприємства як об`єкту управління, що мають прояв у нелінійності зв’язків між ії поточним рівнем та реалізованою сукупністю управлінських дій. Для оцінювання результатів забезпечення економічної безпеки обгрунтовані їі динамічні параметри: операційна досконалість як внутрішня передумова її забезпечення та ринкова стійкість як зовнішня форма прояву внутрішніх системних характеристик бізнесу. Запропоновано методичний підхід до оцінювання результатів забезпечення економічної безпеки підприємства, що грунтується на оцінюванні ступеня відповідності вищезазначених параметрів (забезпечувальних площин) внутрішнім нормативам, середньогалузевим значенням та кращим практикам ведення бізнесу у поточному періоді. Імплементація пропонованого методичного підходу до оцінювання результатів забезпечення економічної безпеки у ретроспективному аспекті дозволила емпірично підтвердити, що внутрішні операційні передумови та ринкові позиції гірничо-металургійних підприємств визначаються використаними / не використаними на певний проміжок часу можливостями бізнес-середовища. Ідентифіковані стилі забезпечення економічної безпеки досліджуваних підприємств. Виявлено, що превалюючим $є$ регресивний стиль, що має прояв у завищенні

\footnotetext{
${ }^{1}$ Криворізький національний університет; професор кафедри обліку, оподаткування, публічного управління та адміністрування; ідентифікатор ORCID: https://orcid.org/0000-0002-9293-2969; e-mail: vladimir.ya15@gmail.com.

${ }^{2}$ Криворізький національний університет; доцент кафедри обліку, оподаткування, публічного управління та адміністрування; ідентифікатор ORCID: https://orcid.org/0000-0003-4145-3711; e-mail: tdutybz.077@gmail.com.
} 
внутрішніх нормативів при небезпечному ступені відповідності кращим практикам ведення бізнесу. Обгрунтовано, що його використання ставить рівень економічної безпеки підприємства у критично небезпечну залежність від ринкової ситуації, а, з урахуванням сучасних тенденцій у економіко-політичному середовищ,і дозволяє спрогнозувати зниження рівня економічної безпеки досліджуваних підприємств вже у найближчій перспективі: падіння світової економіки, посилення протекціонізму на зовнішніх ринках, підвищення податкового навантаження, збільшення ставок екологічного податку тощо. Практичне значення дослідження. Обгрунтовано науковий підхід до забезпечення економічної безпеки підприємства, що інтегрує стратегічний та операційний рівні управління та забезпечує мінімізацію ступеня невідповідності внутрішніх системних характеристик бізнесу вимогам стейкхолдерів і тенденціям зовнішнього середовища на основі використання можливостей нарощення потоків доданої вартості в умовах перманентних динамічних змін функціонування підприємства. Подальші дослідження авторів присвячені розробці методичних підходів до врахування третьої площини забезпечення економічної безпеки «стейкхолдерська задоволеність».

Ключові слова: економічна безпека, забезпечувальні площини, операційна площина, оцінювання, ринкова площина, управлінська парадигма.

Кількість джерел: 11; кількість таблиць: 3; кількість рисунків: 1; кількість формул: 1.

\section{Introduction.}

Acceleration of changes, intensified complexity and ambiguity of the business environment determining the increased number of hazardous impact factors for enterprises' activity are key features of the present-day reality (Nusinov and Mishchuk, 2019). Thus, the results of the fifth global CEO outlook indicate that two thirds of the respondents consider the ability to adapt to changes to be a new currency of business (KPMG in Ukraine, 2019, p. 2). In $2019,67 \%$ of the world CEOs and $91 \%$ of those in Ukraine thought that dynamic responses to new challenges and trends guaranteed survival and security of operating companies. Recent tightening of these requirements is confirmed by the fact that in 2018 that indicator was $8 \%$ smaller (KPMG in Ukraine, 2019 , p. 9). The above mentioned conditions the objective necessity to substantiate new approaches to conceptualizing economic security management which are relevant to up-to-date realities and based on recent achievements of strategy and strategic management theories.

\section{Problem Setting.}

Generalization of key principles of existing theories that form the methodological basis for enterprise management enables us to substantiate priorities for developing the managerial paradigm of security studies including the following:

1) Provision of integrity and coordination of the operating and strategic levels of provision and management. Integration of the operating and strategic levels of ensuring the enterprise economic security will provide managers with commitment based on multi-level combination of activity and accomplishment of processes to guarantee integrated implementation of operations, functions and managerial impacts of individual executers and departments in order to achieve the highest results of their joint activities.

2) The necessity to expand the context of real-world perception. As various hazards and threats occurring in current dynamic conditions are immanent prerequisites for enterprises' functioning, we cannot deny expediency of managers' focusing on these problems, yet opportunities to ensure compliance of business activity with conditions of the external environment are to be considered as well. Concerning the operating level of provision, it is worth mentioning that present-day researches emphasize value chain potentials. As these potentials enable either obtaining or increasing the economic security level in the short-term, we suggest treating them as reserves. 
3) Concrete definition of time horizons for both provision and management. Analytical estimation of the objective reality as integrity of the past, the present and the future creates a relevant informational basis to form an integrated set of managerial actions.

4) Provision of dialectic integrity of sustainability and changeability. Their economic explication implies maintaining the enterprise's identity enhanced by business stability based on ongoing changes and complications. Sustainability of the enterprise's functioning mode and standard accomplishment of its business processes are provided by formed routines - practices of customarily repeated behaviour actions. With that, responses to changes in the external environment on the operating level are reactive by nature. On the other hand, on the strategic level, changeability is based on proactive and creative features. This fact conditions exclusive attention to developing dynamic abilities. Correspondingly, traditional standardized and formalized managerial processes (budgeting, resource planning and control, etc.) are complemented with higher-level processes. They are based on nonformalized, implicit knowledge of applying opportunities to ensuring the desired level of the economic security considering future forecast parameters of the business environment.

5) Expansion of the resource provision context to ensure economic security. Resource provision as a key component of economic security management, in the general context, should be aimed at preventing strategic gaps between resources, knowledge and competences of the enterprise at present and those required to realize strategic intentions and relevant to the vision of the future.

6) Actualization of cognitive aspects while providing and managing economic security. Modern approaches to managing economic security do not deny exclusive importance of the cognitive component, yet they treat it in a fragmentary and contextual manner. However, the authors indicate that managers' cognitive abilities are crucial for efficient identification of threats and business opportunities and their relevant responses. Besides, immaturity of the cognitive component is an internal source of generating threats to enterprises' activity among which we can distinguish constraints in objective reality perception, excessive rationality of economic entities, and untimely changes of managerial stereotypes.

7) Substantiation of economic security parameters as a provision and management object. The nonlinear link between the economic security level and its provision determines the need for substantiating dynamic parameters, which, on the one hand, would present internal properties of the economic system, and, on the other hand, - external forms of their manifestation forming the desired level and state of economic security.

We suggest basing dynamic parameterization of economic security on two provision planes - operational excellence and market sustainability. We consider market sustainability within the scope of the generally established context as the enterprise's positions on a certain industry-related market that enhance its improved activity accompanied by achieved financial results under changeable conditions of the business environment (Tur, 2016 , p. 6). Concerning operational excellence, we share the views of those scholars who define it as an element of the enterprise's organizational leadership revealing itself in reaching the desired state of business processes of the value chain and implementing its resource potentials (Nykyforchyn, 2017; 2018).

\section{Literature review.}

Many researches deal with the issues of ensuring economic security and its components. After analyzing the field-related literature, N. Lysenko and N. Biloshkurska (2014) indicated identification of the mechanism of forming economic security with that of its provision. At the same time, the scholars agree with the existing viewpoint that the mechanism of providing economic security is noted for harmonization of an enterprise's interests and those of external entities by means of 
integrated managerial, economic, motivational and organizational trends aimed at achieving required incomes, this being considered the aim of the enterprise's reaching the economic security condition (Lysenko and Biloshkurska, 2014).

H. Azarenkov and S. Serdechna (2017) accentuate the necessity to consider an enterprise's external and internal environments to ensure its economic security. At the same time, they admit that security provision is based on implementing the enterprise's interests, goals and priorities. The researchers are right to indicate continual character of economic security provision. Their idea should be complimented with consistency of provision emphasized by Yu. Bielik (2016). According to H. Azarenkov and S. Serdechna (2017), the latter includes four stages: monitoring and identification of threats; selection of methods of analyzing the financial state; continual observation of changes in economic security indicators; and application of methods to ensuring security. Where explication of forming economic security is concerned, scholars accentuate development of managerial and economic mechanisms of working out links with the enterprise's external stakeholders (Azarenkov and Serdechna, 2017).

Managerial and economic steps include a variety of methods that enhance the economic security (Fig. 1).

Thus, we support the idea that provision of economic security cannot be unoriginal as all its components are interrelated, their integrated application generates additional (in some cases - synergetic) effects (Bielik, 2016).

Unlike the established division of economic security provision steps into managerial-technological, economic, informational, institutional, legal, administrative, social and psychological ones (Azarenkov and Serdechna, 2017), we consider them interrelated and those to be treated on a single plane. Apart from the above mentioned, Yu. Bielik (2016) adds financial steps and accentuates consideration of the enterprise's specific features and the character of its relations with external stakeholders. Thus, every individual enterprise has its own unique and dynamic methods, mechanisms, tools of ensuring economic security that can be adjusted to changeable conditions of the internal and external environments.

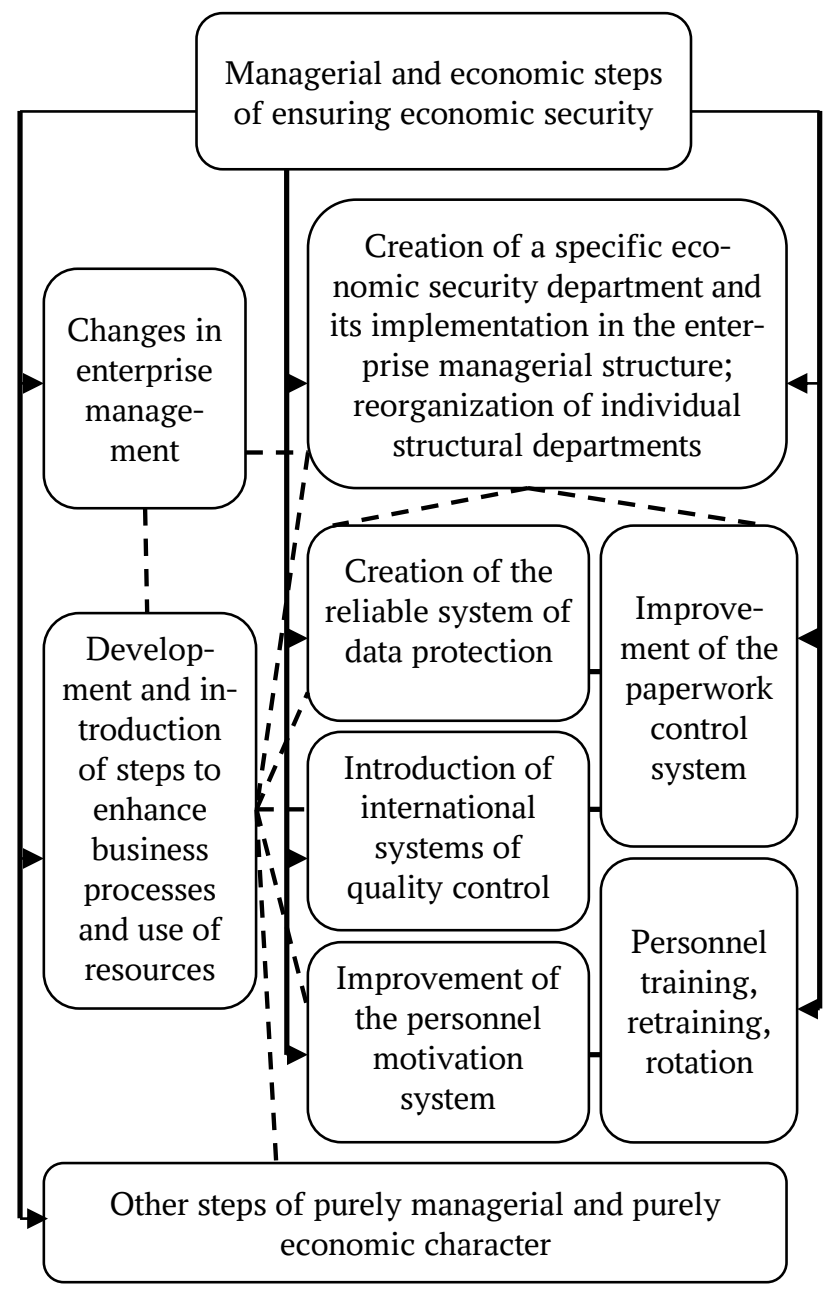

- - - the authors' represenaton of interelations

\section{Fig. 1. Basic managerial and economic steps of ensuring economic security}

Source: summarized by the authors on the basis of (Azarenkov and Serdechna, 2017)

Factors of forming the economic security are conventionally divided into external and internal (Bielous, 2012). External factors include changes on international and currency markets, changes of legislation, social and economic conditions of development on macroand meso-levels, demography, the state policy in various fields of the economic life, etc. Therefore, they are not directly dependent 
upon the enterprise's activity and therefore remain uncontrolled. Yet, when ensuring economic security, they should not only be considered, but also predicted.

As for assessment of economic security, the research by V. Voropai (2013) should be mentioned which contains a list of specified assessment methods, their characteristics, advantages and disadvantages. These methods include indicator-based, programme-based, resource-functional, system-related ones, bankruptcy prediction, application of economicmathematical methods and models, evaluation of the financial component of the enterprise's activity, expert opinion, etc.

\section{Methodology.}

The research applies general scientific theoretical methods like generalization, explanation and grouping to analyzing economists' and practitioners' ideas about the research object and formulating conclusions of the content-analysis of primary sources as well as analysis and synthesis to substantiating a new scientific approach of ensuring economic security.

\section{Research objectives.}

The research aims to elaborate scientific and methodological approaches to ensuring economic security as a key component of its management.

\section{Results and discussions.}

Basic stages of the suggested methodological approach to assessing results of ensuring economic security in the operating plane are as follows:

1) Substantiation of indicators according to specified provision planes that would consider specific features of the economic activity of the enterprises under study and be based on available and trustworthy data.

2) Formation of the statistic database of primary indicators in a certain time period:

$$
\mathrm{X}=\left\{x_{k j}\right\},
$$

where $k$ is the number of the provision plane; $k=1,2 ;(1$ is operational excellence, 2 is market sustainability);

$j$ is the number of the indicator in the $k$-th projection, $j=\overline{1, m_{k}}$;

$m_{k}$ is the number of indicators in the $k$ th provision plane.

3) Standardization of indicators on the basis of the ratio of primary values to 1 ) industry averages; 2) the enterprise's internal standards; 3) the best indices of foreign companies. Due to this, the vector of primary values of attributes $x_{k j}=\left|x_{k 1}, x k_{2}, \ldots, x_{k m_{k}}\right|$ is replaced by the vector of standardized values $z_{k j}=\left|z_{k 1}, z_{k 2}, \ldots, z_{k m_{k}}\right|$. Standardization should consider which indicators are stimulants and which are destimulants.

4) Identification of integrated indicators according to provision planes "Operational excellence" and "Market sustainability" by calculating weighted values by each projection. When choosing this method of forming the integrated indicator we can level experts' subjectivity in defining weight coefficients. It is worth mentioning that it is impossible to identify a single integrated indicator by both provision planes, as the indicators filling these projections are non-additive. Besides, as is shown above, identified projections are multidirectional: operational excellence represents internal prerequisites of economic security, while market sustainability represents external ones.

$5)$ Interpretation of the results obtained. Unlike other methods based on the toolkit of integrated data and providing for qualitative identification of the studied object according to the resulted integrated indicator, the suggested approach implies quality interpretation of economic security management by using a set of indicators of correspondence of the parameter with internal standards, industry averages and best business practices. To do this, the authors have formed a relevant matrix based on the scale which is the most common in various economic researches (Table 1). 
Nusinov V. Ya., Mishchuk le. V. Elaboration of scientific and methodological approaches to providing economic security of an enterprise as a key component of its management

Table 1. General qualitative interpretation of correspondence of economic security provision parameters

\begin{tabular}{|c|c|c|}
\hline $\begin{array}{c}\text { Quantitative value of the } \\
\text { indicator, unit fr. }\end{array}$ & Details of ranking & $\begin{array}{c}\text { Parameter correspondence } \\
\text { degree }\end{array}$ \\
\hline $0.8-1.0$ & High & Maximum/desired \\
\hline $0.60-0.79$ & Mean & Permissible \\
\hline $0.40-0.59$ & Satisfactory & Dangerous \\
\hline $0.20-0.39$ & Low & Critical \\
\hline $0-0.19$ & Unsatisfactory & Catastrophic \\
\hline
\end{tabular}

Source: developed by the authors.

The suggested matrix not only allows qualitative assessment of provision results but also creates preconditions for identification of the economic security provision style on the totality of integrated indicators of the degree of correspondence between provision planes and industry averages, internal standards and best business practices:

- the leadership style is characterized by the proactive response to changes of the business environment, this enabling the enterprise to obtain desired financial results and create benchmarking values of the industry-related indicators totality;

- the harmony style is characterized by proximity to the best industry practices, this enabling maintenance and achievement of the desired economic security level of the enterprise;

- the restraining style is characterized by decrease of internal standards (objectives), this provoking "self-congratulation" of management and, as a result, slows down increase of the economic security level and may lead to the loss of the achieved level;

- the aggressive style is conditioned by management perfectionism in establishing internal standards that surpass the highest industry-related indicators within a certain time period, thus stimulating increase of the economic security parameter level;

- the supporting style is characterized by provision of the maximum level of correspondence of main management parameters with industry averages the level of which within a corresponding period is decreasing due to the unfavourable market situation, this enabling minimization of the economic security level decrease in the period of industry stagnation;

- the regressive style is characterized by inefficient use of reserves and business opportunities that results in the enterprise's decreased ability to satisfy stakeholders' interests and achieve financial growth, this later provoking the economic security level decrease;

- the distorting style is characterized by chaotic managerial decisions and absence of an integrated set of managerial actions disabling increase of the operational excellence level and / or enhancement of market positions, this facilitating fast decrease of the economic security level of the enterprise;

- the damaging style not only disables achievement of the desired economic security level but also threatens operational continuity and results in system misbalance of business.

It should be taken into account that the provision style is characteristic of each provision plane (operational excellence - market sustainability), synergy of which either accelerates the negative trend of losing the economic security level or enables mitigation of negative effects of managerial decisions and actions.

The conceptual difference of successive stages on the strategic provision level consists in priority of top management's cognitive abilities to anticipate and realize future features of the business environment: 
1. The first stage involves analysis of main medium- and long-term trends that underlie principal changes in stakeholders' requirements, production technologies, specific character of doing business in this or that industry.

2. Considering commitment of the strategic level of management to providing correspondence of current enterprise capacities with future business environment parameters, 1) its internal standards are adjusted, industry averages and benchmark indicators are forecast; 2) the totality of primary indicators for assessment is broadened on the basis of the above changes.

3. In accordance with the base of primary indicators and their benchmark / standard values, indicators are standardized with the following determination of the integrated indicator for the developed provision planes (similarly to the retrospective analysis block).

4. Integrated values for each provision plane establish an information basis to adjust the integrated totality of managerial actions in furtherance of the level of correspondence of resource provision from the viewpoint of parameters of the future and development and implementation of prioritized managerial decisions on minimization of strategic gaps and approximation to future requirements.

Thus, the retrospective block of assessing results of economic security provision serves as an indicator of quality, timeliness and correspondence of the implemented totality of integrated managerial actions with the environment of their functioning. The prospective block enables achievement and maintenance of the desired economic security level in the long-term period.

To implement the suggested methodological approach at Ukrainian mining and metallurgical enterprises, it is necessary to substantiate indicators immanent in this business. We have grouped statistic indicators which consider types of economic activities of the enterprises under study, and complement them with those indifferent to the activity types. Leaving aside well-known indicators, we only focus on the essence and choice of some of them from the suggested totality. On the whole, indicators of the provision plane "Operational excellence" present the state of an enterprise based on the following criteria:

- reliability (the ratio of correspondence of fixed assets with world analogues, the average operating lifetime of equipment, etc.);

- optimality (concentrate yield, etc.) ;

- rationality (iron losses in concentration wastes, cast iron consumption for steel production, metal scrap content in the charge, etc.);

- stability (the ratio of the rational structure of costs for acquiring new equipment to its maintenance and modernization, etc.).

Among the indicators of the provision plane "Operational excellence", we present that of iron content in concentrate as the ability of the operating system to maximize the useful component content in marketable products. However, the provision plane "Market sustainability" contains the well-known indicator of the level of correspondence of iron ore product quality with market requirements.

The wide range of metal product quality indicators includes the chemical composition (main component fractions, impurity fractions, geometry, roll surface finish, etc.). Considering the export-orientedness of the metallurgical enterprises' activities and requirements to minimize the indicator range for convenience of business analyses, we suggest assessing metal product quality parameters based on the share of metal products certified according to international standards in the total amount of sales. This is conditioned by non-recognition of Ukrainian certificates in the world and results in obtaining international ones: IAF (International Accreditation Forum) which involves national accreditation bodies of 29 countries; IIOC (Independent International Organisation for Certification) which involves eight large international firms; EQNET (Europe Quality Network) which comprises 21 countries, IQNET (International Certification Network) which comprises over 40 countries. Despite the variety of iron ore products, they all (concentrate, sinter, pellets) are the feed for 
the metallurgical industry with a multiproduct range. Correspondingly, provision of economic security of an enterprise is determined, to a large extent, by its ability to satisfy customized demand and actualizes the value of the rolled-products range indicator.

The product structure based on the degree of raw material processing / the added value level is of importance for market positioning of the enterprises under study and, as a consequence, for generation of desired financial results. The specific character of this indicator for mining and metallurgical enterprises is conditioned by the fact that feed for the next stages (concentrate, cast iron, steel, etc.) may simultaneously be sold on the market as an individual product. At that, the greatest cash flows are generated by products with the greatest added value (pellets, rolled products).

As for including the indicator of the export share in the total sales amount into specific indicators of the mining and metallurgical business, let us point out that volumes of iron ore and metal production greatly exceed domestic demand. So, this indicator is among the key ones that determine ability of the enterprises under study to generate cash flows and, as a result, achieve the desired level of economic security. The export diversification indicator is also gaining importance, this minimizing the level of dependence on suspension of deliveries to the highest demand countries but not decreasing the speed of searching for new markets and transforming transport stream vectors. We suggest calculating this indicator on the basis of the following relations: ExS $_{\text {one country }} \geqslant 0.35 \%$ - standardized value 0; Exs one country $\geqslant 0.25 \%$ - standardized value 0.25 ; Exs $_{\text {one country }} \geqslant 0.15 \%$ - standardized value 0.50 ; Exs $_{\text {one country }} \geqslant 0.10 \%$ - standardized value 0.75; Exsone country $<0.10 \%$ - standardized value 1 (where Exs one country is the share of export to one country).

Weight of this indicator and its value for provision of economic security of metallurgical enterprises specifically is explained by increase in protectionism measures undertaken by governments of countries importing products of the mining and metallurgical enterprises which will be discussed later.

Among the indicators indifferent to economic activity types, we suggest the following ratios that characterize efficiency of marketable product sales and dynamic changes of incomes as compared with expenditures. This list also contains the operating activity security ratio as it is based on indicators of sold, not marketable, products. The obtained results by the provision plane "Operational excellence" are presented in Table 2.

The metallurgical works under study are full cycle enterprises that are part of powerful global integrated structures (ArcelorMittal and "Metinvest"). They are also characterized by a high degree of equipment deterioration with the following average level (in 2013-2014): at the PJSC "ArcelorMittal Kryvyi Rih" - 0.55; at the PrJSC "Azovstal Iron and Steel Works" - 0.33; at the PrJSC "Ilyich Iron and Steel Works of Mariupol" - 0.47. However, along with the technical level, the level of technology is also a problem. Whilst technologies of mining and concentrating production (milling, magnetic separation, flotation) undergo enhancement but not principal changes, metallurgical technologies have changed greatly (direct reduction, scaling of electrometallurgical steel making, etc.). Even continuous casting which is considered an innovation at national steel making enterprises is being applied by majority of countries to produce $100 \%$ of steel. As a result, the industry is characterized by a high level of energy and resource consumption: $30-35 \%$ of the total electric energy consumption and $25-35 \%$ of heat consumption in the industry. The share of fuel and energy resources (FER) in metal products costs makes about 30-40\%, at EU metallurgical enterprises it makes $18-22 \%$.

Costs for raw materials make $45-50 \%$ of product costs (Public information database of the National Securities and Stock Market Commission of Ukraine, 2018). Increased supplies by world leaders complicate the 
economic security state of the enterprises under study, thus enabling the conclusion that reduction of costs as the production efficiency increase factor is transforming into the factor of their current functioning security. Increase of operational excellence as internal properties of the enterprise in terms of reaching the desired economic security level creates preconditions for mining and metallurgical business resistance to market fluctuations.

Table 2. Results of economic security provision at mining and metallurgical enterprises by the provision plane "Operational excellence"

\begin{tabular}{|c|c|c|c|c|c|c|}
\hline \multirow{2}{*}{ Enterprise } & \multicolumn{6}{|c|}{ Years } \\
\hline & 2013 & 2014 & 2015 & 2016 & 2017 & 2018 \\
\hline \multicolumn{7}{|c|}{ Degree of correspondence with internal standards of enterprise } \\
\hline PJSC “Inhulets GZK” & 0.714 & 0.748 & 0.661 & 0.726 & 0.719 & 0.652 \\
\hline PJSC “Southern GZK” & 0.738 & 0.715 & 0.682 & 0.683 & 0.681 & 0.660 \\
\hline PrJSC “Northern GZK” & 0.717 & 0.633 & 0.626 & 0.683 & 0.681 & 0.714 \\
\hline PrJSC “Central GZK” & 0.731 & 0.615 & 0.666 & 0.666 & 0.699 & 0.681 \\
\hline PJSC “ArcelorMittal Kryvyi Rih” & 0.720 & 0.793 & 0.698 & 0.661 & 0.671 & 0.776 \\
\hline PrJSC “Azovstal Iron and Steel Works” & 0.675 & 0.676 & 0.618 & 0.632 & 0.598 & 0.606 \\
\hline PrJSC "Ilyich Iron and Steel Works of Mariupol” & 0.671 & 0.647 & 0.509 & 0.628 & 0.557 & 0.588 \\
\hline \multicolumn{7}{|c|}{ Degree of correspondence with industry averages } \\
\hline PJSC “Inhulets GZK” & 0.919 & 0.967 & 0.925 & 0.910 & 0.928 & 0.909 \\
\hline PJSC “Southern GZK” & 0.845 & 0.873 & 0.915 & 0.852 & 0.874 & 0.854 \\
\hline PrJSC “Northern GZK” & 0.828 & 0.834 & 0.815 & 0.802 & 0.799 & 0.830 \\
\hline PrJSC “Central GZK” & 0.931 & 0.824 & 0.876 & 0.901 & 0.953 & 0.925 \\
\hline PJSC “ArcelorMittal Kryvyi Rih” & 0.983 & 0.958 & 0.973 & 0.948 & 0.962 & 0.962 \\
\hline PrJSC “Azovstal Iron and Steel Works” & 0.938 & 0.932 & 0.928 & 0.946 & 0.940 & 0.900 \\
\hline PrJSC Ilyich Iron and Steel Works of Mariupol & 0.919 & 0.952 & 0.927 & 0.954 & 0.904 & 0.862 \\
\hline \multicolumn{7}{|c|}{ Degree of correspondence with best business practices } \\
\hline PJSC “Inhulets GZK” & 0.550 & 0.583 & 0.515 & 0.614 & 0.527 & 0.554 \\
\hline PJSC “Southern GZK” & 0.567 & 0.551 & 0.530 & 0.546 & 0.546 & 0.521 \\
\hline PrJSC “Northern GZK” & 0.574 & 0.548 & 0.505 & 0.556 & 0.553 & 0.579 \\
\hline PJSC “Central GZK” & 0.587 & 0.476 & 0.527 & 0.524 & 0.601 & 0.518 \\
\hline PJSC “ArcelorMittal Kryvyi Rih” & 0.603 & 0.562 & 0.558 & 0.543 & 0.542 & 0.625 \\
\hline PrJSC “Azovstal Iron and Steel Works”” & 0.561 & 0.545 & 0.501 & 0.515 & 0.474 & 0.501 \\
\hline PrJSC "Ilyich Iron and Steel Works of Mariupol" & 0.561 & 0.523 & 0.472 & 0.505 & 0.447 & 0.476 \\
\hline \multicolumn{7}{|c|}{ Quality interpretation of provision style } \\
\hline PJSC “Inhulets GZK” & \multirow{3}{*}{\multicolumn{3}{|c|}{ Regressive }} & $\begin{array}{c}\text { Sup- } \\
\text { porting }\end{array}$ & \multicolumn{2}{|c|}{ Regressive } \\
\hline PISC "Southern GZK" & & & & \multirow{2}{*}{\multicolumn{3}{|c|}{ Regressive }} \\
\hline PrJSC “Northern GZK” & & & & & & \\
\hline PrJSC “Central GZK ” & \multirow{2}{*}{$\begin{array}{l}\text { Support- } \\
\text { ing }\end{array}$} & \multicolumn{3}{|c|}{ Regressive } & $\begin{array}{c}\text { Sup- } \\
\text { porting }\end{array}$ & $\begin{array}{l}\text { Regres- } \\
\text { sive }\end{array}$ \\
\hline PJSC “ArcelorMittal Kryvyi Rih” & & \multicolumn{4}{|c|}{ Regressive } & $\begin{array}{c}\text { Support- } \\
\text { ing }\end{array}$ \\
\hline $\begin{array}{l}\text { PrJSC "Azovstal Iron and Steel Works" } \\
\text { PrISC "Ulvich Iron and Steel Works }\end{array}$ & \multicolumn{6}{|c|}{ Regressive } \\
\hline
\end{tabular}

Source: calculated by the authors on the basis of the suggested approach.

On the whole, the style of providing economic security of mining and metallurgical enterprises as formation of preconditions for efficient use of the resource potential during main business processes of creating the added value is regressive. It is not oriented at use of opportunities and implementation of reserves for operational excellence reaching the best world business practices. 
Nusinov V. Ya., Mishchuk le. V. Elaboration of scientific and methodological approaches to providing economic security of an enterprise as a key component of its management

The integrated indicators of economic se- plane "Market sustainability" are given in curity provision at the mining and Table 3. metallurgical enterprises by the provision

Table 3. Indicators of economic security provision at the mining and metallurgical enterprises by the provision plane "Market sustainability"

\begin{tabular}{|c|c|c|c|c|c|c|}
\hline \multirow{2}{*}{ Enterprise } & \multicolumn{6}{|c|}{ Years } \\
\hline & 2013 & 2014 & 2015 & 2016 & 2017 & 2018 \\
\hline \multicolumn{7}{|c|}{ Degree of correspondence with internal standards of enterprise } \\
\hline PJSC “Inhulets GZK” & 0.603 & 0.589 & 0.531 & 0.619 & 0.665 & 0.584 \\
\hline PJSC “Southern GZK” & 0.701 & 0.658 & 0.602 & 0.668 & 0.679 & 0.678 \\
\hline PrJSC “Northern GZK” & 0.717 & 0.639 & 0.569 & 0.671 & 0.695 & 0.671 \\
\hline PrJSC “Central GZK” & 0.752 & 0.651 & 0.755 & 0.791 & 0.856 & 0.741 \\
\hline PJSC “ArcelorMittal Kryvyi Rih” & 0.734 & 0.816 & 0.770 & 0.922 & 0.947 & 0.940 \\
\hline PrJSC “Azovstal Iron and Steel Works” & 0.649 & 0.686 & 0.635 & 0.695 & 0.681 & 0.749 \\
\hline PrJSC "Ilyich Iron and Steel Works of Mariupol” & 0.795 & 0.663 & 0.769 & 0.669 & 0.783 & 0.795 \\
\hline \multicolumn{7}{|c|}{$\begin{array}{c}\text { Degree of correspondence with industry averages } \\
\end{array}$} \\
\hline PJSC “Inhulets GZK” & 0.713 & 0.716 & 0.763 & 0.749 & 0.762 & 0.746 \\
\hline PJSC “Southern GZK” & 0.968 & 0.975 & 0.960 & 0.920 & 0.910 & 0.969 \\
\hline PrJSC “Northern GZK” & 0.999 & 0.990 & 0.891 & 0.999 & 0.999 & 0.999 \\
\hline PrJSC “Central GZK” & 0.981 & 0.979 & 0.997 & 0.996 & 0.991 & 0.951 \\
\hline PJSC “ArcelorMittal Kryvyi Rih” & 0.831 & 0.938 & 0.792 & 0.969 & 0.955 & 0.963 \\
\hline PrJSC “Azovstal Iron and Steel Works” & 0.839 & 0.868 & 0.836 & 0.761 & 0.763 & 0.803 \\
\hline PrJSC "Ilyich Iron and Steel Works of Mariupol" & 0.912 & 0.789 & 0.904 & 0.780 & 0.732 & 0.905 \\
\hline \multicolumn{7}{|c|}{ Degree of correspondence with best business practices } \\
\hline PJSC “Inhulets GZK” & 0.520 & 0.500 & 0.447 & 0.527 & 0.582 & 0.500 \\
\hline PJSC “Southern GZK” & 0.595 & 0.558 & 0.507 & 0.598 & 0.604 & 0.582 \\
\hline PrJSC “Northern GZK” & 0.606 & 0.537 & 0.483 & 0.573 & 0.598 & 0.597 \\
\hline PrJSC “Central GZK” & 0.639 & 0.516 & 0.621 & 0.682 & 0.702 & 0.601 \\
\hline PJSC “ArcelorMittal Kryvyi Rih” & 0.638 & 0.726 & 0.664 & 0.794 & 0.792 & 0.819 \\
\hline PrJSC “Azovstal Iron and Steel Works” & 0.588 & 0.668 & 0.567 & 0.730 & 0.580 & 0.763 \\
\hline PrJSC "Ilyich Iron and Steel Works of Mariupol" & 0.584 & 0.601 & 0.564 & 0.604 & 0.580 & 0.686 \\
\hline \multicolumn{7}{|c|}{ Quality interpretation of provision style } \\
\hline PJSC “Inhulets GZK" & \multirow{2}{*}{\multicolumn{6}{|c|}{ Regressive }} \\
\hline $\begin{array}{l}\text { PJSC “Southern GZK” } \\
\text { PrISC “Northern GZK" }\end{array}$ & & & & & & \\
\hline PrJSC “Central GZK” & Supp. & $\begin{array}{l}\text { Regres- } \\
\text { sive }\end{array}$ & \multicolumn{4}{|c|}{ Supporting } \\
\hline PJSC “ArcelorMittal Kryvyi Rih” & \multicolumn{6}{|c|}{ Supporting } \\
\hline PrJSC “Azovstal Iron and Steel Works” & \multirow{2}{*}{$\begin{array}{l}\text { Re- } \\
\text { gres. }\end{array}$} & \multirow{2}{*}{ Supp. } & \multirow{2}{*}{ Regres. } & \multirow{2}{*}{ Supp. } & \multirow{2}{*}{$\begin{array}{c}\text { Re- } \\
\text { gres. }\end{array}$} & \multirow{2}{*}{ Supp. } \\
\hline PrJSC "Ilyich Iron and Steel Works of Mariupol" & & & & & & \\
\hline
\end{tabular}

Source: calculated by the authors on the basis of the suggested approach.

Statistic data demonstrate that export diversification is one of the most important factors influencing achievement and maintenance of the desired level of economic security at the enterprises under study. This is explained by the following: limited domestic demand for products of mining and metallurgical enterprises; increased protectionism measures and trade barriers in different countries (tariff quotas, protection and antidumping duties, etc.); force majeure (pandemic, etc.); increased iron ore production of world leaders (which are 
competitive due low operating costs and the dominant position in seaborne logistics (trade).

The mining and concentration enterprises are characterized by the mostly regressive style in terms of cash flow increase and, consequently, provision of the desired economic security level. Products of the national enterprises do not meet modern requirements of European stakeholders in terms of their quality that allows use of iron ore products in direct reduction processes. This results in the poor export structure. As for metallurgical enterprises, it is reasonable to focus on the PJSC “ArcelorMittal Kryvyi Rih" which is described by the supporting type of provision. This can be explained largely by foreign experience of management directed at maximal market potential use limited by the technical and technological base that slows down achievement of the highest level of operational excellence. In spite of the limited rolling width, (as compared with the PrJSC “Azovstal Iron and Steel Works" and the PrJSC "Ilyich Iron and Steel Works of Mariupol”), the PJSC "ArcelorMittal Kryvyi Rih" is characterized by the best sales structure and the most diversified export markets.

\section{Conclusions.}

Thus, summarizing the obtained results of economic security provision at the mining and metallurgical enterprises by the provision plane "Operational excellence", the following trends can be determined: firstly, the well-established management practice which is manifested in decreased internal standards of the enterprise; secondly, the high level of correspondence with industry averages which is determined by entirely the scale of their activities and corresponding significant influence on industry values formation; thirdly, a traditionally dangerous degree of compliance with the best world mining and metallurgical practices as security of the enterprises under study is largely determined by the export potential due to limited domestic demand. Detailed treatment of the analysis results demonstrates that non-compliance with both internal standards and the best world business practices is mostly conditioned by unreasonable managerial concentration on modernization of available equipment with the share for acquiring innovative equipment being critically low.

The research results prove that enterprises' positioning according to their market sustainability is determined by used / not used opportunities within a certain period. The mining and concentration enterprises have not used their opportunities to increase their activities on the basis of increased quality parameters of products that satisfy stakeholders' requirements. This has provoked the poor export structure threatening the economic security level. The enterprises of the Metinvest holding have not been able to satisfy the customized demand for metal products either, prevalence of sinter, cast iron and steel in their sales structure creates a threat for the metallurgical business.

\section{References}

Azarenkov, H. F., Serdechna, S. M. (2017), "Formation of analytical tools to ensure economic security of strategic development of the enterprise", Molodyi vchenyi, no. 5(45), pp. 508-517.

Bielik, Yu. V. (2016), “Theoretical principles of economic security of enterprises: essence, significance and provision”, Molodyi vchenyi, no. 12.1 (40), pp. 636-640.

Bielous, N. D. (2012),"Theoretical generalization of components and factors of formation of economic security of enterprises", Zbirnyk naukovykh prats VNAU. Ekonomichni nauky, no. 1(56), issue 3, pp. 73-83.

KPMG in Ukraine (2019), "Look for talent or lose. The view of leaders in Ukraine 2019", available at: https:/home.kpmg/ua/uk/home/media/press-releases/2019/06/osnovni-zahrozy-dlya-zrostannyabiznesu.html (Accessed 20 October 2019).

Lysenko, N. O. and Biloshkurska, N. V. (2014), Ekonomiko-orhanizatsiinyi mekhanizm formuvannia ekonomichnoi bezpeky ahropromyslovykh pidpryiemstv [Economic and organizational mechanism of formation of economic security of agro-industrial enterprises], VPTs «Vizavi» (Vydavets «Sochinskyi»), Uman, Ukraine, $257 \mathrm{p}$. 
Nusinov V. Ya., Mishchuk le. V. Elaboration of scientific and methodological approaches to providing economic security of an enterprise as a key component of its management

Nusinov, V. Ya. and Mishchuk, Ie. V. (2019), "Use of speed indicators in assessing and ensuring economic security of enterprises”, Economies' Horizons, no. 1(8), pp. 14-24, doi: https://doi.org/10.31499/2616$\underline{5236.1(8) .2019 .161733}$

Nykyforchyn, M. D. (2017), “An integrated approach to managing the operational efficiency of the enterprise”, Ekonomika. Finansy. Pravo, no. 12/5, pp. 36-43.

Nykyforchyn, M. D. (2018), "Methodical approach to assessing the state of operational efficiency management of the enterprise", Ekonomika. Finansy. Pravo, no. 4/3, pp. 51-60.

Public information database of the National Securities and Stock Market Commission of Ukraine (2018), "Report of PJSC “Donetsk Metal Rolling Plant”, available at: https://stockmarket.gov.ua/cabinet/xml/show/bus text/30215 (Accessed 20 October 2019).

Tur, O. V. (2016), “Market stability of the enterprise in modern economic science”, Naukovi pratsi NUKhT, vol. 22, no. 3, pp. 55-63.

Voropai, V. A. (2013), "Analysis of methodological approaches to assessing the state and level of economic security of the enterprise”, Kultura narodov Prychernomoria, no. 257, pp. 190-195.

Цей твір ліцензовано на умовах Ліцензії Creative Commons «/з Зазначенням Авторства - Некомериійна 4.0 Міжнародна» (CC BY-NC 4.0). This is an open access journal and all published articles are licensed under a Creative Commons "Attribution-NonCommercial 4.0 International" (CC BY-NC 4.0). 